\title{
EKSISTENSI PESANTREN DAN DERADIKALISASI PENDIDIKAN ISLAM DI INDONESIA (Menyemai Spirit Toleransi dan Pendidikan Islam Multikultural)
}

\author{
Mualimul Huda \\ Institut Agama Islam Negeri Kudus \\ hudamahbubi@gmail.com
}

\begin{abstract}
Religious life in Indonesia is very dynamic with the emergence of various cases set to religious radicalism.. The phenomenon is not only growing at a particular community, but its existence has been developing in the form of transnational institution. Even pesantren as part of Islamic tradition of archipelago is often associated as' base or central understanding of Islam fundamental become root for growth radical movement that in the name of Islam. The radicalization of understanding at certain pesantren huts that impact on acts of radicalism in Indonesia should be laid in the context of the development of transnational Islamic movements due to the various developments of the existing world. The results of this study concluded that Islam as a universal religion of love (rahmatan lil 'alamin) which teaches education by upholding human values, respecting human rights, respecting cultural and cultural diversity, craving peace, justice, tolerance and a balanced attitude, and other noble manifestations. Dogmatic groups that justify acts of violence in the name of religion have reduced and injured the teachings of rahmatan lil 'alamin. Islamic education (Pesantren) that teaches hatred against different opinions and beliefs is not ideal for the continuity of diversity and diversity in Indonesia. Pesantrens infiltrated by radicalization need to be reoriented in a direction compatible with the Islamic spirit that teaches mutual respect and brotherhood. A number of values that are taught are tolerant, moderate, togetherness, equality, mutual respect and degrees of Islamic multicultural education
\end{abstract}

Keywords : Pesantren, Deradicalization, Islamic Education, Multicultural

\begin{abstract}
Abstrak
Kehidupan beragama di Indonesia sangat dinamis dengan munculnya berbagai kasus yang berlatar belakang radikalisme keagamaan. Fenomena tersebut tidak hanya berkembang pada komunitas tertentu, namun eksistensinya sudah berkembang dalam bentuk yang bercorak transnasional. Pesantren sebagai bagian dari tradisi Islam Nusantara seringkali diasosiasikan sebagai sentral pemahaman Islam fundamental menjadi akar bagi bersemainya gerakan radikal yang mengatasnamakan Islam. Salah satu upaya deradikalisasi agama adalah melakukan proses pemahamanan dan pembentukan pola pikir, yakni dengan menanamkan niilai multikulturalisme melalui pendidikan pesantren. Hasil penelitian ini disimpulkan bahwa Islam sebagai agama kasih sayang universal (rahmatan lil 'alamin) yang mengajarkan pendidikan dengan menjunjung tinggi nilai-nilai kemanusiaan, menghargai hak-hak asasi manusia,
\end{abstract}

FOKUS : Jurnal Kajian Keislaman dan Kemasyarakatan Vol. 3, No. 1, 2018

P3M Sekolah Tinggi Agama Islam Negeri (STAIN) Curup - Bengkulu

Available online: http://journal.staincurup.ac.id/index.php/JF

p-ISSN 2548-334X, e-ISSN 2548-3358 
menghormati ragam budaya dan kultur masyarakat, mengidamkan kedamaian, keadilan, toleransi, dan sikap yang seimbang, dan manifestasi akhlak mulia lainnya. Pendidikan Islam (pesantren) yang mengajarkan kebencian terhadap pendapat dan keyakinan yang berbeda sangatlah tidak ideal bagi kelangsungan kebhinekaan dan keragaman di Indonesia. Pesantren yang terinfiltrasi oleh radikalisasi perlu reorientasi ke arah yang sesuai dengan spirit Islam yang mengajarkan saling menghargai dan persaudaraan. Sejumlah nilai yang diajarkan adalah toleransi, moderat, kebersamaan, kesederajatan, saling menghargai dan pendidikan Islam multikultural.

Kata Kunci: Pesantren, Deradikalisasi, Pendidikan Islam, Multikultural

\section{PENDAHULUAN}

Secara historis tumbuh dan kembangnya Islam di Indonesia dengan damai dan toleran relevan dengan apa yang diajarkan oleh para wali melalui sinkronitas budaya lokal yang ada di nusantara, perbedaan kultur dan ras tidak menjadikan pertentangan bahkan permusuhan pada masa itu. Sejalan dengan perkembangan zaman serta demokrasi dan tuntutan stratifikasi sosial di tengah masyarakat Indonesia yang begitu masif, maka bermunculanlah sekte-sekte, aliran-aliran, dan mazhab-mazhab baru yang mengatasnamakan Islam berkembang pesat sesuai dengan latar belakang kebudayaan dan kondisi alam yang eksis di daerah penganutnya ${ }^{1}$. Munculnya aliran-aliran Islam "garis keras" yang baru di Indonesia tidak bisa dilepaskan dari reformasi itu sendiri, demokrasi berkembang memberikan ruang terbuka bagi aliran-aliran Islam untuk menyuarakan ide dan gagasannya secara fulgar pasca tumbangnya rezim Orde Baru².

Indonesia merupakan salah satu negara yang memiliki pluralitas penduduk yang tinggi. Pluralitas itu meliputi pluralitas etnis, suku, budaya dan agama. Oleh karena itu, diperlukan adanya semangat toleransi antar suku, etnis, budaya dan agama tersebut, demi menghindari terjadinya konflik yang mengarah pada tindak kekerasan atau tindakan

1 Asrori A, "Radikalisme di Indonesia: Antara Historisitas dan Antropisitas", Kalam, Vol. 9, No. 2, 2015, diakses di journal.radenintan.ac.id/index.php/KALAM/ article/.../331/187, https://doi.org/10.24042/ klm.v9i2.331, hlm. 253-268.

${ }^{2}$ Hasan. Laskar Jihad: Islam, Militancy, and the Quest for Identity in Post-New Order Indonesia, (Ithaca: Cornell Southeast Asia Program Publications, 2006), hlm. 1325 . 
radikal. ${ }^{3}$ Khusus mengenai pluralitas agama, di Indonesia rasa saling toleransi beragama masih sangat minim, diperlukan kesadaran dari masing-masing umat beragama untuk menjunjung tinggi nilai toleransi melalui sikap saling menghormati antar umat beragama yang lainnya. Hal ini didukung dengan hadirnya fakta munculnya permasalahanpermasalahan yang diikuti dengan anarkisme atau kekerasan yang mengatas namakan agama. Hal ini jelas sangat mengkhawatirkan bagi intregritas bangsa Indonesia sendiri. Radikalisme dengan mengatasnamakan agama di Indonesia menjadi perhatian serius dari berbagai elemen. Fenomena tersebut tidak hanya berkembang pada komunitas tertentu. Namun, eksistensinya sudah berkembang dalam bentuk yang bercorak transnasional. Hal itu dikarenakan hampir di seluruh negara terdapat fenomena radikalisme agama. Bahkan radikalisme agama juga bercorak transreligius karena dialami oleh semua agama yang berkembang di dunia ini. Apabila gerakan Islam radikal ini dibiarkan tumbuh kembang, maka akan berdampak lebih besar terhadap kerukunan umat beragama, terlebih dengan kondisi bangsa Indonesia yang kaya akan keberagaman.

Islam adalah agama kasih sayang universal, bahkan pemahaman Islam yang berkembang di Indonesia adalah pemahaman Islam yang rahmatan lil'alamin. Islam yang senantiasa menjunjung tinggi nilai-nilai kemanusiaan, menghargai hak-hak asasi manusia, menghormati ragam budaya dan kultur masyarakat, mengidamkan kedamaian, keadilan, toleransi, dan sikap yang seimbang. Melihat fakta seperti ini pertanyaan yang muncul adalah mengapa ada sejumlah kelompok radikal yang mengatasnamakan Islam?

Sebagian kaum Muslimin bisa saja berapologi bahwa aksi radikal bukanlah aksi melainkan reaksi atas tatanan politik dunia yang berpihak pada Barat dan merugikan negara-negara Islam. Sebagian kaum Muslimin

${ }^{3}$ Eko Wahyu Jamaluddin, Suprayogi Suprayogi, dan Aris Munandar, "Pembinaan Nilai Toleransi Beragama di Pondok Pesantren Annuriyyah Soko Tunggal Semarang" Unnes Civic Education Journal, Vol. 1, No. 1 2015, diakses di https://journal.unnes.ac.id/sju/index.php/ucej/issue/view/31 pada tanggal 02 Juli 2017 hlm. 17 . 
bahkan berdalih bahwa kekerasan atas nama agama termasuk jihad amar ma'ruf nahi munkar dan menegakkan syariat Islam secara menyeluruh (kaffah). Selanjutnya, dalam konteks Indonesia, diskursus radikalisme agama Islam selalu dikaitkan dengan lembaga pendidikan tradisional, yakni pesantren. Bahkan pesantren ini merupakan salah satu bentuk pendidikan keagamaan di Indonesia yang mendapatkan perhatian secara khusus, lebih-lebih setelah terjadinya beberapa tindakan radikal yang mengatasnamakan agama. ${ }^{4}$

Sebagai lembaga pendidikan berbasis keislaman yang khas Indonesia pesantren telah menegaskan arti penting dalam menyebarkan budaya damai. Pesantren sejak awal perkembangannya merupakan lembaga pendidikan yang moderat dan akomodatif terhadap perbedaan-perbedaan yang ada di masyarakat. ${ }^{5}$ Konsep tasāmuḥ, tawassuṭ, tawāzun, dan i'tidāl yang melekat pada komunitas pesantren merupakan bukti nyata, bahwa pesantren merupakan institusi yang menyemaikan nilai-nilai perdamaian dan anti terhadap radikalisme. Sebenarnya, dikaitkannya Islam radikal dengan pesantren ini merupakan sesuatu yang ambigu. Sebab lahirnya pesantren di Indonesia sebagai lembaga pendidikan keagamaan sebenarnya tidak didirikan untuk melahirkan radikalisme. Melainkan pesantren bertugas untuk mencetak kader-kader ulama yang berpengetahuan luas tentang agama (tafaqquh fi'l-dīn). ${ }^{6}$

Oleh karenanya eksistensi pesantren sebagai agen perubahan (agent of change) bagi masyarakat dalam diskursus global diharapkan mampu menjadi struktur mediasi (mediating structure) untuk memahami persoalan-persoalan yang muncul dalam masyarakat dan dapat

4 Masduqi, "Deradikalisasi Pendidikan Islam Berbasis Khazanah Pesantren", Jurnal Pendidikan Islam, Vol.II, No.1, 2013, diakses di http://ejournal.uinsuka.ac.id/tarbiyah/JPI/article/view/1125 pada tanggal 25 Mei 2018, hlm. 2.

${ }^{5}$ Muammar Ramadhan, "Deradikalisasi Agama melalui Pendidikan Multikultural dan Inklusivisme (Studi Pada Pesantren al-Hikmah Benda Sirampog Brebes)”, Jurnal SMART (Studi Masyarakat, Religi, dan Tradisi), Vol. 1, No. 2, 2015, diakses di https://blasemarang.kemenag.go.id/journal/index.php/smart/article/view/250, pada tanggal 01 Juli 2018, hlm. 177-90. hlm. 16 .

${ }^{6}$ Wahid, Pondok Pesantren Masa Depan, (Bandung: Pustaka Hidayah, 1999), 
menjembatani pemberdayaan masyarakat demi terwujudnya cita-cita bersama membentuk civil society. Karena pesantren yang "ramah" dengan masyarakat, pada ranah sosial-budaya, politik, ekonomi, lembaga ini juga mampu berperan sebagai lokomotif dan dinamisator dalam mengawasi perubahan. Pada kenyataannya isu terorisme ini juga dibenturkan dengan eksistensi pesantren yang sudah lama diakui oleh masyarakat mempunyai peran penting dalam pengembangan dan terus memfasilitasi aktivitas sosial-keagamaan masyarakat. Ini merupakan suatu belenggu atas kebebasan pesantren sehingga membentuk opini masyarakat yang selalu bertanya mungkinkah pendidikan Islam (umum) mengajarkan teologi kebencian terhadap aliran dan agama yang berbeda kepada anak didiknya? mungkinkah pendidikan islam yang justru menumbuhkan benih-benih intoleransi dan sikap ekslusif? Jika gerakan radikalisasi di lembaga-lembaga pendidikan Islam memang benar adanya, lalu bagaimana cara menanggulanginya? Pertanyaan-pertanyaan yang sudah lama berada dalam kehidupan bermasyarakat yang sangat segera untuk ditemukan solusinya untuk menata kembali pendidikan Islam yang lebih toleran, inklusif, dan humanis demi terciptanya masyarakat madani. Kajian Kajian ini termasuk kajian library research dengan menggunakan pendekatan kualitatif yang dianalisis secara deskriptif.

\section{PEMBAHASAN}

\section{Eksistensi Pesantren sebagai Lembaga pendidikan Islam di Indonesia}

Pesantren merupakan lembaga pendidikan Islam yang khas dan otentik Indonesia. Pesantren dengan berbagai variansnya dalam sejarah Indonesia dapat ditelusuri keberadaannya sampai Abad ke-13 M sebagai lembaga pendidikan yang berkembang subur di pedesaan dan daerah terpencil. Perkembangan selanjutnya menunjukkan pondok pesantren tumbuh sebagai bagian dari dakwah Islam di Pulau Jawa oleh para wali yang biasa disebut sebagai Walisongo. Peranan Walisongo dalam pondok pesantren ini makin diperkuat dengan keberpihakan penguasa kerajaan Islam, seperti Sultan Agung di Kerajaan Mataram Islam. Terkait asalmuasal terbentuknya lembaga pendidikan Islam ini pun masih menjadi 
objek perdebatan dan kajian yang terus berkembang. Perdebatan atau setidaknya perbedaan pandangan terjadi antara mereka yang melihat bahwa pondok pesantren merupakan produk asli Indonesia, mereka yang melihat pondok pesantren sebagai derivasi model pendidikan Hindu di India, maupun yang berpendapat bahwa keislaman di Baghdad saat berada dalam puncak keemasan Islam merupakan inspirasi bagi pembentukan lembaga pendidikan Islam di Indonesia. Apapun pendapat yang dikemukakan, secara umum pondok pesantren diakui sebagai lembaga yang menjaga tugas mulia dalam penyebarluasan ajaran Islam di Nusantara.

Dalam struktur pendidikan nasional, pesantren merupakan mata rantai yang sangat penting. Hal ini tidak hanya karena sejarah kemunculannya yang sangat lama, tetapi karena pesantren telah secara signifikan ikut andil dalam upaya mencerdaskan kehidupan bangsa. ${ }^{7}$ Bukti bahwa sistem pendidikan pesantren ada sejak sebelum kedatangan Islam adalah adanya beberapa istilah yang digunakan di lingkungan pesantren. Pikiran masyarakat Indonesia pada umumnya menghormati, mengutamakan, serta mendahulukan orang tua, dan karena pada umumnya "orang berilmu" itu sudah berumur, maka mereka mendapat julukan "kiai" dan khususnya di Jawa Barat disebut "ajengan" yang berarti pemuka. Murid-murid dari kiai itu disebut "santri". Istilah ini sudah ada sebelum kedatangan Islam. Oleh karena itu, tempat berkumpulnya para santri disebut pesantren. ${ }^{8}$

Berbagai kajian dan penelitian yang difokuskan pada pesantren dalam rangka menggali lebih dalam apa yang sebenarnya terjadi pada pesantren, seperti sistem pendidikannya, adat kebiasaannya, pengaruh pesantren terhadap masyarakatnya, juga keterlibatan kiai sebagai pemegang otoritas pesantren dalam kehidupan politik, bahkan peran dalam merespon globalisasi. Karena itu, pesantren sebagai lembaga pendidikan Islam indigenous Indonesia secara wajar mendapatkan perhatian khusus guna pengembangan ke arah pembangunan pendidikan

\footnotetext{
${ }^{7}$ Abdul Hady Mukti et al., Pengembangan Metodologi Pembelajaran di Salafiyah, (Jakarta: Departemen Agama RI, 2002), hlm.1.

${ }^{8}$ Eko Wahyu Jamaluddin, dkk., Op.cit., hlm. 128.
} 
nasional. Pesantren sebagai lembaga pendidikan mampu membentuk pola pikir dan perilaku santrinya. Wahid menjelaskan bahwa fungsi pesantren adalah sebagai upaya menjaga konstruksi keagamaan yang benar sebagaimana dipegang oleh masyarakat muslim dan imam-imam besar di masa lampau, yang dikenal dengan konsep Ahl-as-Sunnah. ${ }^{9}$

Manfred Zimek dalam Prasojo (1982) mengkategorikan pesantren ke dalam lima kategori, yaitu: 1) pesantren yang paling sederhana yaitu masjid digunakan sekaligus sebagai tempat pengajaran agama. Biasanya digunakan oleh para santri yang ikut kegiatan tarikat dan santri tidak tinggal di pesantren. Hal inilah sebagai cikal bakal berdirinya sebuah pesantren; 2) pesantren di samping ada rumah kiai dan masjid, ada asrama yang dapat dijadikan sebagai tempat belajar sekaligus tempat tinggal, inilah yang sering disebut pondok klasik; 3) pesantren terdiri dari beberapa komponen, selain adanya komponen-komponen di atas, diperluas lagi dengan adanya madrasah. Hal ini menunjukkan dorongan modernisasi dari Islam pembaharuan. Pesantren ini di samping mempelajari pengetahuan agama, mengkaji nahwu, shorof, dan kaidah bahasa Arab lainnya, juga mempelajari tentang pengetahuan umum, kurikulum yang digunakan berorientasi pada sekolah yang berada di bawah organisasi pemerintah; 4) pesantren paling modern yang sekarang sedang berkembang dan terus bergema di seluruh Indonesia, hampir semua pondok pesantren mengembangkan tipe ini. Pesantren model ini di samping adanya fasilitas yang lengkap juga program-program tambahan yang bisa dijadikan sebagai alat untuk mengembangkan ilmunya setelah selesai mengenyam pendidikan di pesantren. Hal ini menunjukkan dorongan modernisasi dari Islam pembaharuan. Pesantren tidak hanya mempelajari pengetahuan agama, mengkaji nahwu, shorof, dan kaidah bahasa Arab lainnya, juga mempelajari tentang pengetahuan umum, kurikulum yang digunakan berorientasi pada sekolah yang berada di bawah organisasi pemerintah; 5) pesantren paling modern yang sekarang sedang berkembang dan terus bergema diseluruh Indonesia, hampir semua pondok pesantren mengembangkan tipe ini. Pesantren model ini di

\footnotetext{
${ }^{9}$ Ibid., hlm.13.
} 
samping adanya fasilitas yang lengkap juga program-program tambahan yang bisa dijadikan sebagai alat untuk mengembangkan ilmunya setelah selesai mengenyam pendidikan di pesantren. ${ }^{10}$

Iqbal dalam bukunya Tajdid fikr Ad Din fi al Islam menyatakan bahwa tujuan pendidikan adalah mencetak manusia. Bagi Islam, manusia adalah makhluk yang terdiri dari jasad dan ruh. Artinya, makhluk jasadiyah dan ruhaniyah sekaligus. Keduanya harus dikelola dari manusia secara seimbang agar kelak lahir manusia yang utuh ruhiyyah dan jasadiyyah. Manusia yang utuh akan bisa menyeimbangkan permasalahan antara urusan duniawi dan urusan ukhrawi. Ketika ini sudah berjalan beriringan manusia tersebut akan menjadi baik. Al Attas menjelaskan bahwa tujuan pendidikan Islam adalah menolong pelajar untuk menjadi manusia utuh yaitu manusia yang memiliki kesadaran jati diri dan nasib spiritualnya, melalui ilmu pengetahuan yang benar dan tingkah laku yang baik. ${ }^{11}$ Dengan demikian, pendidikan seharusnya memperhatikan dimensi realitas, kapasitas, potensi fisik, intelektual dan spiritual dari peserta didik yang seimbang. Untuk itu diperlukan ruang untuk adanya keterbukaan peserta didik dengan lingkungan belajarnya, dengan tujuan pembelajaran yang berlangsung akan memberikan hasil yang diharapkan.

\section{Fungsi dan Peran Pesantren dalam menyemai Pendidikan Islam Moderat}

Pesantren termasuk lembaga pendidikan tertua di Indonesia. Pesantren bahkan sudah ada sejak sebelum Indonesia merdeka. Pondok pesantren merupakan dunia tradisional Islam yang mampu mewarisi dan memelihara kesinambungan tradisi Islam yang dikembangkan ulama dari masa ke masa, tidak terbatas pada periode tertentu. Oleh karena itu, ketahanan lembaga pesantren agaknya secara implisit menunjukkan bahwa dunia Islam dalam segi-segi tertentu masih tetap relevan di tengah perkembangan zaman. Keniscayaan bahwa pesantren tetap utuh hingga

${ }^{10}$ Prasodjo, et.all., Profil Pesantren Laporan Hasil Penelitian Pesantren AlFalak dan Delapan Pesantren Lain di Bogor, (Jakarta: LP3ES, 1982), hlm. 37.

${ }_{11}$ Muhammad Naquib Al-Attas, The concept of education in Islam, (Muslim Youth Movement of Malaysia, 1980), hlm. 30. 
kini bukan hanya disebabkan kemampuannya dalam melakukan akomodasi-akomodasi tertentu, tetapi juga lebih banyak disebabkan karena karakter eksistensialnya. Karakter yang dimaksud adalah, sebagaimana dikatakan Nurcholish Madjid, pesantren tidak hanya menjadi lembaga yang identik dengan makna keislaman, tetapi juga mengandung makna keaslian Indonesia. ${ }^{12}$

Sebagai lembaga yang murni berkarakter keindonesiaan, pesantren muncul dan berkembang dari pengalaman sosiologis masyarakat sekitar, sehingga antara pesantren dengan komunitas lingkungannya memiliki keterkaitan erat yang tidak bisa terpisahkan. Hal ini tidak hanya terlihat dari hubungan latar belakang pendirian pesantren dengan lingkungan tertentu, tetapi juga dalam pemeliharaan eksistensi pesantren itu sendiri melalui pemberian wakaf, sadaqah, hibah, dan sebagainya. Sebaliknya, pihak pesantren melakukan 'balas jasa' kepada komunitas lingkungannya dengan bermacam cara, termasuk dalam bentuk bimbingan keagamaan, sosial, kultural, dan ekonomi. Dalam konteks terakhir inilah, pesantren dengan kiainya memainkan peran yang disebut Clifford Geertz sebagai 'cultural brokers' (pialang budaya) dalam pengertian seluas-luasnya.

Di samping karakter keindonesiaan, pesantren senantiasa mentransmisikan pemahaman keagamaan Islam yang ramah, damai, toleran, saling menghargai, dan tidak radikal. Jauh dari doktrin terorisme, saling mengkafir-bid'ahkan, apalagi pembenaran atas letupan-letupan bom bunuh diri. Dalam kondisi Indonesia yang komplek dan plural, pondok pesantren telah memainkan peranan yang strategis. Ia mampu melakukan penyebaran agama dan pemahaman yang damai, toleran, dan menjunjung tinggi nilai-nilai kemanusiaan dan kebangsaan. Pesantren telah mampu merekatkan dari berbagai perbedaan di masyarakat. Oleh karenanya, tidak berlebihan jika pesantren menjadi garda terdepan dalam membangun pemahaman Islam yang Rahmatan lil'alamin.

${ }^{12}$ Rini Dwi Susanti, "Menguak Multikulturalisme di Pesantren (Telaah Atas Pengembangan Kurikulum)," ADDIN, Vol. 4, No. 2, 2012, diakses di http://id.portalgaruda.org/?ref=browse \&mod=viewarticle \&article=251956, pada tanggal 02 Juli 2017, hlm. 319. 
Fungsi pondok pesantren sebagai lembaga dakwah Islam dapat tercapai dengan sukses apabila ia dapat memainkan perannya dengan baik. Peran pesantren dapat dipetakan menjadi 2 hal, yaitu: internal dan eksternal. Peran internal adalah mengelola pesantren ke dalam yang berupa pembelajaran ilmu agama kepada para santri. Sedangkan peran eksternal adalah berinteraksi dengan masyarakat termasuk pemberdayaan dan pengembangannya ${ }^{13}$. Menurut Mastuhu, sebagaimana dikutip Oepen, ada 10 prinsip pendidikan yang berlaku pesantren. Kesepuluh prinsip itu menggambarkan ciri utama tujuan pendidikan pesantren, antara lain: memiliki kebijaksanaan menurut ajaran Islam, memiliki kebebasan yang terpimpin, artinya kebebasan yang terbatas, berkemampuan mengatur diri sendiri, memiliki kebersamaan yang tinggi, menghormati orang tua dan guru, cinta kepada ilmu pengetahuan, mandiri, dan kesederhanaan. ${ }^{14}$ Prinsip-prinsip di atas menunjukkan bahwa pendidikan pesantren sangat memperhatikan pembinaan moral dan etika, sehingga pondok pesantren sebagai fungsi pendidikan moral sangatlah efektif dan efisien.

Setidaknya terdapat lima substansi yang dikembangkan oleh pondok pesantren. Pertama, Pesantren mengajarkan nasionalisme. Sejarah membuktikan bahwa Negara Kesatuan Republik Indonesia (NKRI) diperjuangkan oleh ulama-ulama. Para kiai dan santri memiliki 'saham' besar dalam membentuk bangsa dan negara ini. Sejak awal, nasionalisme sudah tertanam kuat dalam dada para santri. Pesantren menanamkan kesadaran akan cinta Tanah Air. Cinta Tanah Air bahkan bisa dijadikan sebagai salah satu standar kualitas keimanan seorang muslim. Ahlussunnah wal jamaah memahami, syariat dan nilai-nilai agama bisa ditegakkan di masyarakat, ketika daerah atau negara dalam kondisi damai. Artinya, kedamaian menjadi syarat mutlak, apabila tiba-tiba ada orang Islam yang mengajarkan kekerasan dan mentolerir pembunuhan atas nama agama, maka perlu dipertanyakan kembali keIslamannya. Karena hal ini akan meruntuhkan sendi-sendi kehidupan berbangsa dan

\footnotetext{
${ }^{13}$ Jamaluddin, Metamorfosis Pesantren di Era Globalisasi, hlm. 134.

${ }^{14}$ Manfred Oepen dan Walgan Karcher, Dinamika Dunia Pesantren, (Jakarta: P3M, 1988), hlm.280-288.
} 
bernegara. Tidak satupun pesantren yang menolak pondasi dasar negara; Pancasila, UUD 45, NKRI, dan Bhineka Tunggal Ika. Kedua, pendidikan pesantren menanamkan ajaran-ajaran Islam yang toleran. Toleransi merupakan basis dan pilar pendidikan Islam di pesantren. Pesantren senantiasa menghargai akan perbedaan pendapat yang berbeda dan jauh dari klaim-klaim kebenaran tunggal. Insan pesantren tidak pernah menganggap apa yang mereka yakini sebagai sebuah kebenaran, adalah kebenaran yang mutlak. Banyak pesantren mengikuti pendapat Imam Syafi'i: "pendapatku itu adalah sesuatu yang benar menurutku, tetapi boleh jadi, pendapatku itu salah". Dalam pesantren, kebenaran itu tidak mutlak pada dirinya. Bahkan perbedaan bisa menimbulkan simpati, bahkan empati. Jadi, pesantren melihat perbedaan sebagai sebuah rahmat, lanjutnya. Meski demikian mengingatkan, toleran bukan berarti, menerima atau meyakini keyakinan yang beda tersebut. Ketiga, pendidikan Islam di pesantren mengajarkan Islam yang moderat, tidak ekstrim radikal dan tidak ekstrim liberal. Keseimbangan dan penguatan akan nilai-nilai moderasi (tawazun) ini telah menjadi kekhasan lembaga pendidikan pesantren. Keempat, pesantren menghargai keragaman agama, budaya, dan etnis (multikulturalisme) yang diarahkan dalam rangka lita'arafu (agar saling mengenal), bukan litabaghadu (saling membenci dan memusuhi). Kelima, pendidikan pesantren mengajarkan Islam yang bersifat inklusif, bukan eksklusif. Pesantren terbuka dan menerima siapapun, termasuk non-muslim. Kelima pilar inilah yang selama ini diajarkan di pondok-pondok pesantren.

Peran dan karakteristik pesantren inilah yang di antaranya membedakan antara pesantren dengan lembaga pendidikan Islam lainnya. Sekolah, madrasah, dan perguruan tinggi agama Islam merupakan bentuk improvisasi dan modernisasi lembaga pendidikan yang mengadopsi dari dunia luar. Kehadiran lembaga-lembaga pendidikan ini jauh lebih belakangan dibanding pondok pesantren. Demikian juga, lembagalembaga ini tidak hanya dimiliki oleh Indonesia, tetapi juga terdapat di dunia muslim lainnya, bahkan dengan tingkat kualitas yang lebih baik. 


\section{Pesantren dan Deradikalisasi Pendidikan Islam: Menyemai Spirit Pendidikan Islam Multikultural}

Dalam konteks pendidikan, pesantren merupakan sebuah lembaga yang hidup dan berkembang sangat dinamis. Banyak ruang yang dapat diperbincangkan, karena ia selalu menarik, segar, dan aktual. Dinamika pesantren dan interaksinya dengan masyarakat yang diperankan oleh santri, kiai, dan alumni pesantren semakin memperteguh kembali bahwa pesantren merupakan bagian dari infrastruktur masyarakat. Secara mikro maupun makro, pesantren telah berperan menyadarkan komunitas masyarakat untuk berpegang pada idealisme, mengembangkan kemampuan intelektual, dan perilaku mulia untuk menata serta membangun karakter bangsa yang makmur dan berperadaban.

Pesantren sebagai bagian dari tradisi Islam Nusantara seringkali diasosiasikan sebagai markas atau sentral pemahaman Islam fundamental menjadi akar bagi gerakan radikal yang mengatasnamakan Islam. Islam Nusantara menjadikan Aswaja sebagai patokan dalam pilar kehidupan beragama dan bermasyarakat. ${ }^{15}$ Aswaja merupakan paham keislaman yang sudah diajarkan oleh para ulama salaf generasi sahabat dan tabi'in yang dikenal moderat (tawassuth, tawazun, i'tidal), dan menghindari anarki atau kekacauan dalam masyarakat. Namun pada kenyataannya, ajaranajaran agama yang membawa misi perdamaian, kerukunan, persatuan, keadilan memberikan dan menjamin HAM telah tereduksi oleh pemahaman fanatis terhadap teks-teks agama yang ahistoris. ${ }^{16}$ Dilihat dari eksistensinya, pesantren mempunyai banyak dimensi yang terkait, karakter plural, tidak seragam, dan tidak memiliki wajah tunggal. Pesantren kelihatan berpola seragam, tapi beragam; tampak konservatif, tetapi secara diam-diam atau terang-terangan mengubah diri dan mengimbangi denyut perkembangan zamannya. Pesantren merupakan suatu lembaga pendidikan klasik dan mungkin paling tradisional, akan

${ }^{15}$ Baso, Islam Nusantara: Ijtihad Jenius dan Ijma'Ulama Indonesia, (Jakarta: Pustaka Afid, 2015), hlm. 31.

16 Qodir, "Deradikalisasi Islam dalam Perspektif Pendidikan Agama", Jurnal Pendidikan Islam, Vol. II, No. 1, 2013, diakses di http://ejournal.uinsuka.ac.id/tarbiyah/JPI/article/view/1129/1025 pada tanggal 2 Juni 2018, hlm. 87. 
tetapi justru semakin survive, dan bahkan dianggap sebagai lembaga pendidikan alternatif dalam era globalisasi dan modernisasi sekarang ini. ${ }^{17}$

Radikalisme (al-tat'arruf) secara bahasa artinya adalah berdiri di posisi ekstrem dan jauh dari posisi tengah-tengah atau melewati batas kewajaran. Radikalis merupakan suatu paham yang menghendaki adanya perubahan, pergantian, dan penjebolan terhadap suatu sistem di masyarakat sampai ke akarnya, bilamana perlu menggunakan cara-cara kekerasan. ${ }^{18}$ Kaum radikal menginginkan adanya suatu perubahan dalam tatanan kehidupan bermasyarakat dan beragama selanjutnya menganggap bahwa rencana-rencana yang digunakan adalah rencana yang paling ideal. Melakukan perubahan (pembaruan) merupakan hal yang wajar dilakukan bahkan harus dilakukan demi menuju masa depan yang lebih baik. Namun, perubahan yang sifatnya revolusioner seringkali "memakan korban" lebih banyak sementara keberhasilannya tidak sebanding. Oleh sebab itu, sebagian ilmuwan sosial menyarankan perubahan dilakukan secara perlahan-lahan tetapi kontinu dan sistematik, daripada revolusioner tetapi tergesa-gesa. ${ }^{19}$

Azyumardi Azra menegaskan bahwa yang dimaksud radikalisme Islam adalah ide-ide, pemikiran, ideologi, dan gerakan Islam yang mengarah kepada aktivitas intimidasi, kekerasan dan teror, baik karena doktrin keagamaan, membela diri, maupun bentuk respons terhadap lawan politik yang ditunjuknya ${ }^{20}$. Radikalisme tidak hanya dibatasi oleh sikap dan tindakan keras (fisik) semata, radikalisme merupakan bentuk perlawanan dari individu kepada individu atau kelompok lain yang berseberangan melalui pemikiran maupun tindakan-tindakan intimidasi.

17 Abdurrahman Kasdi, "Pendidikan Multikultural di Pesantren: Membangun Kesadaran Keberagamaan yang Inklusif”, ADDIN, Vol.4, No.2, 2012, diakses di http://id.portalgaruda.org/ ?ref=browse \&mod=viewarticle \&article=251937 pada tanggal 03 Juli 2018, hlm. 214.

${ }^{18}$ Ibid., hlm. 7.

${ }^{19}$ Stompka, Sosiologi Perubahan Sosial, (Jakarta: Kencana Prenada Media Group, 2009), hlm. 223.

20 Afandi, "Menghadang Radikalisme di Bumi Nusantara", Lentera: Kajian Keagamaan, Keilmuan, dan Teknologi, Vol. 2, No. 1, 2016, hlm. 73-87. 
Terkait dengan radikalisme, Allah swt berfirman,"Katakanlah: Hai Ahli Kitab, janganlah kamu berlebih-lebihan (melampaui batas) dengan cara tidak benar dalam agamamu" (QS.5:77). Rasulullah bersabda, "Jauhilah perilaku melampaui batas. Sesungguhnya kerusakan umat terdahulu disebabkan oleh perilaku yang melampaui batas dalam agama". Hadis ini muncul dalam rangka mengkritik perilaku sahabat yang melewati batas dalam melempar jumrah dengan menggunakan batu yang besar. Meskipun hadis ini muncul dalam konteks historis yang khusus, namun beberapa ulama menyatakan bahwa hadis ini berlaku untuk semua bentuk radikalisme. Secara istilah, radikalisme adalah fanatik kepada satu pendapat serta menegasikan pendapat orang lain, mengabaikan terhadap kesejarahan Islam, tidak dialogis, suka mengkafirkan kelompok lain yang tak sepaham, dan tekstual dalam memahami teks agama tanpa mempertimbangkan tujuan esensial syariat (maqashid al-syari'at). ${ }^{21}$

Sementara itu, deradikalisasi adalah sebuah proses untuk merubah sikap dan cara pandang yang dianggap keras menjadi lunak; toleran, pluralis, dan moderat. Dengan demikian, deradikalisasi adalah counter radikalisasi. Jika radikalisasi melahirkan radikalisme yang ditandai dengan sikap kaku, keras, tanpa kompromi, maka deradikalisasi ditujukan untuk menjadikan seseorang menjadi lunak, toleran, pluralis, dan moderat. Hal yang perlu digaris bawahi dari radikalisasi dan deradikalisasi adalah keduanya memerlukan sebuah proses pengenalan, penanaman, penghayatan, dan penguatan. ${ }^{22}$

Yusuf al-Qardhawi dalam Hanafi (2000) menjelaskan beberapa solusi untuk mengatasi masalah radikalisme antara lain; pertama, menghormati aspirasi kalangan Islamis radikalis melalui cara-cara yang dialogis dan demokratis; kedua, memperlakukan mereka secara manusiawi dan penuh persaudaraan; ketiga, tidak melawan mereka dengan sikap yang samasama ekstrem dan radikal. Artinya, kalangan radikal ekstrem dan

${ }^{21}$ Masduqi, Op.cit., hlm. 434.

22 Karwadi, "Deradikalisasi Pemahaman Ajaran Islam," Al-Tahrir: Jurnal Pemikiran Islam, Vol. 14, No. 1, 2014, diakses di http://jurnal.stainponorogo.ac.id/index.php/tahrir/article/view/71, pada tanggal 03 Juli 2018, hlm. 142 . 
kalangan sekuler ekstrem harus ditarik ke posisi moderat agar berbagai kepentingan dapat dikompromikan; keempat, dibutuhkan masyarakat yang memberikan kebebasan berpikir bagi semua kelompok sehingga akan terwujud dialog yang sehat dan saling mengkritik yang konstruktif dan empatik antara aliran-aliran; kelima, menjauhi sikap saling mengkafirkan dan tidak membalas pengkafiran dengan pengkafiran; keenam, mempelajari agama secara benar sesuai dengan metode-metode yang sudah ditentukan oleh para ulama Islam dan mendalami esensi agama agar menjadi Muslim yang bijaksana; ketujuh, tidak memahami Islam secara parsial dan reduktif; kedelapan, sebaiknya kalangan radikal lebih mempertimbangkan kondisi dan situasi serta kemampuan kaum muslimin yang sangat beragam. Artinya, tidak bijaksana apabila kalangan radikal memaksakan kehendaknya tanpa mempertimbangkan kelemahan dan rintangan yang dihadapi oleh kaum Muslimin yang awam; kesembilan, seyogyanya kalangan radikal memahami urutan perintah dan larangan agama yang harus diprioritaskan untuk dikerjakan atau dijauhi; kesepuluh, kalangan radikal seyogyanya memegang prinsip bahwa perbedaan dalam masalah ijtihad adalah keniscayaan sehingga mereka tidak terjebak dalam klaim kebenaran tunggal. Dalam menyikapi perbedaan yang ada di masyarakat, diperlukan gagasan damai dan rasa saling menghormati satu dengan yang lain. ${ }^{23}$

Gagasan damai sejatinya mampu memupuk berlangsungnya kesejahteraan hidup dan keselamatan manusia di muka bumi. Hal ini karena misi perdamaian merupakan cita-cita yang tertuang secara substansial dan faktual dalam teks keislaman. Akan tetapi, gagasan mendalam tentang misi perdamaian dari agama-agama, terutama agama Ibrahim, seakan-akan tertutup oleh gagasan kekerasan yang hanya masalah furu'iyyah dari agama-agama. ${ }^{24}$ Terlepas dari indahnya ajaran agama, memang harus diakui, bahwa salah satu faktor radikalisme adalah karena motivasi agama, yaitu karena proses radikalisasi agama dan

\footnotetext{
${ }^{23}$ Hanafi, Islam in the Modern World: Tradition, Revolution and Culture, (Cairo: Dar Kebaa Bookshop, 2000), hlm. 3-4.

${ }^{24}$ El-Fadhl, Atas Nama Tuhan, (Jakarta: Serambi, 2004), hlm. 234.
} 
interpretasi serta pemahaman keagamaan yang kurang tepat dan keras yang pada gilirannya melahirkan sosok muslim fundamentalis yang cenderung ekstrim terhadap kelompok lain dan menganggap orang lain yang berbeda sebagai musuh sekalipun satu agama, apalagi berbeda agama. Teks-teks agama ditafsirkan secara atomistik, parsial-monolitik (monolithic-partial), sehingga menimbulkan pandangan yang sempit dalam beragama. ${ }^{25}$

Jika kita melihat kurikulum yang ada di pesantren tentunya akan menimbulkan sebuah benang merah, bahwa pesantren dan terorisme bukanlah dua hal yang patut dihubung-hubungkan, karena ini akan mereduksi peran lembaga pendidikan Islam tersebut dalam mewujudkan transformasi ajaran-ajaran agama Islam kepada masyarakat. Bahkan lebih dari itu, masyarakat juga akan semakin apatis terhadap pesantren. Organisasi atau lembaga manapun tidak akan bisa berkembang secara optimal apabila terus berkutat pada interaksi internal (inward looking). Disinilah pemberian legitimasi dari pemerintah terkait dengan problematika terhadap pesantren menjadi amat penting.

Pesantren sebagai salah satu lembaga pendidikan yang mentransfer nilai dan pengetahuan (transfer of values and knowledge), memiliki fungsi sosial dan sangat berperan dalam mewujudkan kehidupan yang penuh kedamaian dan harmonis bagi masyarakat pada umumnya. Perannya adalah untuk memberikan pemahaman kepada peserta didik mengenai pentingnya menentukan pilihan nilai yang akan dijadikan pegangan hidupnya, seperti kebebasan, persamaan, toleransi, kesetiakawanan, keadilan, kejujuran, dan kesabaran, baik dalam lingkup lembaga pendidikan, masyarakat, maupun negara. ${ }^{26}$ Kepercayaan masyarakat terhadap keberadaan pesantren sebagai pendidikan agama pada usia anak-anak sudah mulai diragukan, mereka khawatir anakanaknya akan diindoktrinasi ajaran-ajaran radikal, rupanya mereka telah

${ }^{25}$ Qodir, Op.cit., hlm. 88.

${ }^{26}$ Mukhibat, "Deradikalisasi dan Integrasi Nilai-Nilai Pluralitas dalam Kurikulum Pesantren Salafi Haraki di Indonesia", Al-Tahrir: Jurnal Pemikiran Islam, Vol. 14, No. 1, 2014, diakses di http://jurnal.stainponorogo.ac.id/index.php/tahrir/ article/view/121, pada tanggal 03 Juli 2018, hlm.193. 
terprovokasi oleh isu-isu internasional. Islam selalu mewajibkan umatnya untuk berbuat baik kepada sesama, karena Islam adalah agama damai yang tercermin dalam interaksi sosial para santri dalam pesantren.

Sikap saling menghormati, toleransi terhadap individu lain sejalan dengan ajaran Islam (pendidikan) yaitu islam sebagai pembawa misi keTuhanan berusaha menciptakan maslahah, perdamaian, persatuan, keadilan, kesetaraan, menjahi tindakan radikal. ${ }^{27}$ Terlebih aksi-aksi kekerasan yang dilakukan dengan mengatasnamakan agama, mengatasnamakan jihad, membela Tuhan dengan embel-embel agama lainnya. Islam sebagai agama rahmatan lilalamin melindungi umat manusia secara mutlak, tanpa melihat latar belakang ideologi, etnis dan bangsa. Inilah salah satu bentuk sikap yang diharapkan timbul dari pendidikan beragama yaitu bersifat inklusif, universal dan transending. Sikap inklusif dalam beragama adalah hal utama yang perlu untuk dikembangkan, dimana agar masyarakat tidak mudah terpancing dalam berbagai konflik yang bernuansa agama karena pandangan ekslusif beragama yang salah. Langkah langkah yang perlu diambil pembangunan paradigma keberagamaan dari ekslusif ke inklusif melalui pendidikan islam (pesantren).

Inklusivisme (keterbukaan) merupakan alternatif untuk mengantisipasi hadirnya fanatisme dan ekslusivisme dalam kehidupan beragama yang dapat memicu munculnya radikalisme. Upaya deradikalisasi membutuhkan pondasi pemikiran multikulturalisme. Ada beberapa prinsip dari multikulturalisme yaitu; pertama, kaum Muslimin harus menyadari bahwa perbedaan adalah keniscayaan yang tidak bisa dipungkiri lagi. Dikatakan niscaya sebab teks-teks agama Islam bersifat multi-interpretatif (yahtamilual-aujuh); kedua, perbedaan umat Islam adalah rahmat dan bentuk kekayaan khazanah kebudayaan Islam yang justru akan membuat kaum Muslimin semakin dinamis dan leluasa menentukan pilihan pendapatnya; ketiga, kaum Muslimin berusaha

27 Abdurrahman Kasdi, "Pendidikan Multikultural di Pesantren: Membangun Kesadaran Keberagamaan yang Inklusif', ADDIN, Vol.4, No.2, 2012, diakses di http://id.portalgaruda.org/ ?ref=browse \&mod=viewarticle\&article=251937 pada tanggal 03 Juli 2018, hlm. 213. 
memilih pendapat yang moderat, sebab di dalam khazanah keilmuan Islam terdapat pendapat-pendapat ulama yang keras yang sebaiknya dijauhi; keempat, menjauhi sikap mengklaim kebenaran sepihak; kelima, saling tolong-menolong dalam masalah yang disepakati oleh semua golongan; keenam, toleransi dalam masalah-masalah yang diperselisihkan oleh ulama. Prinsip kelima dan keenam ini terinspirasi dari slogan Rasyid Ridha dalam Tafsiral-Manar yang berbunyi "Kita harus saling menolong dalam masalah yang disepakati dan saling toleran dalam masalah yang diperdebatkan". Yang dimaksud dengan toleransi adalah menghormati pendapat orang lain dan tidak fanatik kepada satu pendapat serta tidak mudah menyesatkan pendapat yang lainnya; ketujuh, menghormati pendapat orang lain dengan menyadari bahwa kebenaran mungkin tercecer di mana-mana. ${ }^{28}$

Prinsip pendidikan Islam multikultural dibutuhkan untuk meningkatkan kesadaran saling menghargai dan menghormati sesama. Pendidikan multikulturalisme yang menekankan pembentukan karakter anak didik yang memiliki sikap simpati, menghormati, mengapresiasi dan empati pada orang lain sudah semestinya menjadi tujuan pendidikan Islam. Para sosiolog juga meyakini bahwa pendidikan multikulturalisme merupakan solusi yang bagus untuk menciptakan harmoni antar elemenelemen yang berbeda dari sebuah bangsa. ${ }^{29}$ Pendidikan inklusif dan multikultur yang terbingkai dalam pendidikan humanis saat ini sangat mendesak untuk diterapkan di pesantren dan lembaga pendidikan lainnya di tengah maraknya indoktrinasi.

Pendidikan Islam multikulturalis menekankan pada pentingnya kontrol emosi dalam menyikapi perbedaan. Imamal-Ghazāli dalam Ihya' Ulum al-Din, mengulas pentingnya kontrol emosi ('ila jal-ghadhab) dalam

\footnotetext{
${ }^{28} \mathrm{Al}$-Qardhawi, Al-Shahwah al-Islämiyyah baynal-Ikhtilaf al-Masyru'wa alTafarruq al- Madzmum:Dirasah fi Fiqh al-Ikhtilaf fi Dhau' al-Nususwaal-Maqasid alIslamiyah, (Bankal- Taqwa, 406 H), hlm. 59-88.

${ }^{29}$ Geneva Gay, A Synthesis of Scholarship in Multicultural Education in Urban Education Monograph Series, (Washington: NCREL's Urban Education Program, 1994), hlm. 2. Dikutip oleh Sirajuddin M, The "Application of Multicultural Education in Pesantren" in International Journal of Pesantren Studies. (Ciputat: PSPP, 200), hlm. 34.
} 
menghargai perbedaan. Menurutnya, selama manusia bisa mencintai dan membenci maka manusia tidak akan lepas dari emosi dan kemarahan. Manusia selalu mencintai pendapat yang cocok dengannya dan membenci hal-hal yang tidak sesuai. Namun, manusia harus mengendalikan emosinya ketika menyaksikan hal-hal yang tak sesuai dengan keinginannya. Kontrol emosi dapat dilakukan melalui enam langkah yaitu: pertama, merenungi keutamaan memaafkan dan menahan amarah sebagaimana firman Allah dalam Quran Surat Al-Imran ayat 34; kedua, takut pada siksa Allah terhadap pemarah; ketiga, menghindari ekses negatif dari permusuhan; keempat, membayangkan raut wajah yang amat jelek seperti anjing dan binatang buas saat marah-marah; kelima, berpikir ulang tentang penyebab kemarahan, dan; keenam, menyadari bahwa kemarahan keluar dari kesombongan karena pemarah merasa seakan-akan perilakunya sesuai dengan maksud Allah. Hal ini mirip dengan fenomena kelompok radikal yang teriak Allahu Akbar tetapi dengan penuh amarah bertindak $\operatorname{kasar}^{30}$.

Pendidikan Islam yang mengedepankan konsep yang memandang manusia seutuhnya jika dikaitkan dengan proses pendidikan berarti berusaha mengoptimalkan segenap kefitrahan (potensi kognitif, afektif dan psikomotorik) manusia untuk mewujudkan kesejahteraan eksistensi kehidupan manusia di dunia yang dilandasi dengan nilai-nilai ajaran Islam. Sehingga pendidikan Islam yang humanis akan terwujud jika diterapkannya sikap menjunjung tinggi dan mengoptimalkan berbagai fitrah manusia dalam rangka mewujudkan insan kamil dan bermanfaat bagi diri sendiri dan orang lain ${ }^{31}$. Eksistensi manusia pun akan tercipta sebagai makhluk yang humanis. Pendidikan Islam yang humanismultikultural harus menjadi orientasi dan aplikasi dalam praktek pendidikan. Semua kegiatan pendidikan harus memiliki implikasi dengan tugas kehidupan manusia di dunia yaitu sebagai khalifah di muka bumi.

${ }^{30}$ Al-Ghazali, Ihya'Ulumal-Din, (Beirut: Dara-Kutubal-'Ilmiyyah, 2002), hlm. $227-233$

31 Baharuddin, Pendidikan Alternatif Qaryah Thayyibah, (Yogyakarta: LkiS, 2007), hlm. 15. 
Pendidikan multikultutalisme sangat ditekankan dalam al-Quran. Allah Swt. Berfirman dalam Q.S Al-Hujurat ayat 13 :

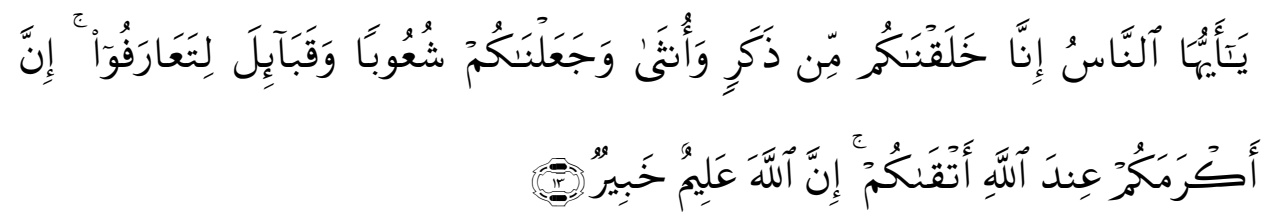

Artinya: "Hai manusia, Sesungguhnya kami menciptakan kamu dari seorang laki-laki dan seorang perempuan dan menjadikan kamu berbangsa - bangsa dan bersuku-suku supaya kamu saling kenalmengenal. Sesungguhnya orang yang paling mulia diantara kamu disisi Allah ialah orang yang paling taqwa diantara kamu. Sesungguhnya Allah Maha mengetahui lagi Maha Mengenal”. (QS. Al-Hujurat : 13).

Konstruksi pendidikan ini berorientasi pada proses penyadaran dan pemahaman agama yang berwawasan pluralitas, sekaligus berwawasan multikultural. ${ }^{32}$ Berbagai krisis multidimensi yang ada di Indonesia, diakui atau tidak merupakan bagian dari problem kultural yang salah satu penyebabnya adalah keragaman kultur yang ada di masyarakat kita. Keragaman kultur seharusnya bukan menjadi penyebab adanya diskriminasi, ketidakadilan, kecurigaan dan berbagai pelanggaran HAM, tetapi menjadi kekuatan untuk membangun kebersamaan. Pemikiran multikulturalisme yang ada di Indonesia disandarkan pada Islam sebagai sumber pemikiran. Dengan penerapan pendidikan multikultural, diharapkan pesantren mampu mendorong peserta didik untuk memiliki kesadaran dan pemahaman untuk selalu menjunjung tinggi nilai-nilai keadilan, demokrasi, kemanusiaan dan pluralisme dalam pergaulan di tengah realitas kebangsaan yang penuh dengan kebhinekaan. Dalam kerangka yang lebih jauh, konstruksi pendidikan Islam pluralismultikultural dapat diposisikan sebagai bagian dari upaya secara komprehensif dan sistematis untuk mencegah dan menanggulangi

\footnotetext{
${ }^{32}$ Mukhibat, Op.Cit., hlm 12.
} 
konflik etnis agama, radikalisme agama, separatisme, dan integrasi bangsa. ${ }^{33}$

Menurut Yusuf Qardhawi sebagaimana yang dikutip oleh Masduqi (2013), bahwa upaya deradikalisasi membutuhkan pondasi pemikiran multikulturalisme yang terdiri dari beberapa prinsip: pertama, kaum Muslimin harus menyadari bahwa perbedaan adalah keniscayaan yang tidak bisa dipungkiri lagi. Dikatakan niscaya sebab teks-teks agama Islam bersifat multiinterpretatif (yahtamilu al-aujuh). Hal ini terbukti dari keteladanan para sahabat yang terlibat dalam perbedaan penafsiran sejak masa kenabian, sehingga saat ini kaum Muslimin hendaknya tidak saling mengkafirkan hanya persoalan berbeda penafsiran; kedua, perbedaan umat Islam adalah rahmat dan bentuk kekayaan kebudayaan Islam yang justru akan membuat kaum muslimin semakin dinamis dan leluasa menentukan pilihan pendapatnya; ketiga, setelah mengetahui keragaman pendapat dalam khazanah pemikiran Islam, sebaiknya kaum muslimin berusaha memilih pendapat yang moderat, sebab di dalam khazanah keilmuan Islam terdapat pendapat-pendapat ulama yang keras yang sebaiknya dijauhi; keempat, menjauhi sikap mengklaim kebenaran sepihak; kelima, saling tolong-menolong dalam masalah yang disepakati oleh semua golongan; keenam, toleransi dalam masalahmasalah yang diperselisihkan oleh ulama. Prinsip kelima dan keenam terinspirasi dari slogan tokoh yang bernama Rasyid Ridha dalam Tafsir al-Manar yang berbunyi "Kita harus saling menolong dalam masalah yang disepakati dan saling toleran dalam masalah yang diperdebatkan". Yang dimaksud dengan toleransi adalah menghormati pendapat orang lain dan tidak fanatik kepada satu pendapat serta tidak mudah menyesatkan pendapat yang lainnya; ketujuh, menghormati pendapat orang lain dengan menyadari bahwa kebenaran mungkin tercecer di mana-mana. Prinsip ketujuh ini terinspirasi dari pendapat para pakar

${ }^{33}$ Ngainun Naim dan Achmad Sauqi, Pendidikan Multikultural: Konsep dan Aplikasi, (Yogyakarta: Ar-Ruzz Media, 2008), hlm. 12. 
ushul fiqh tentang kemungkinan adanya kebenaran yang lebih dari satu (imkan ta'adud al-shawab). ${ }^{34}$

Berkaitan dengan implementasi pendidikan multikultural dalam membangun kesadaran peserta didik untuk menyikapi keragaman yang ada di Indonesia, maka yang dapat dilakukan diantaranya beberapa hal, yaitu: 1) membangun sikap persamaan derajat (equality), guru/ kiai/ ustadz dalam konteks ini harus mendorong kesadaran multikultural dengan membangun semangat empati, equality dan toleransi kepada peserta didik. Dengan menekankan bahwa perbedaaan adalah sunnatullah, setiap orang dengan latar belakang apapun memiliki persamaan dalam haknya sebagai warga negara Indonesia; 2) mendorong demokrasi substansial, pengasuh pesantren memiliki peran mendorong untuk menegakkan demokrasi sebagai sarana membangun konsensus seluruh warga negara Indonesia; dan 3) pendidikan multikulturalisme yang menekankan pembentukan karakter anak didik yang memiliki sikap simpati, menghormati, mengapresiasi dan empati pada orang lain sudah semestinya menjadi tujuan pendidikan Islam; 4) mengembangkan model pembelajaran yang mengedepankan sikap uswah hasanah, kejujuran sekaligus suka memberi maaf kepada orang lain. Dengan internalisasi inilah, maka santri dan masyarakat saling menghargai perbedaan yang ada, bersikap moderat serta memahami prinsip agama Islam sebagai rahmatan lil 'alamin.

\section{PENUTUP}

Pesantren sebagai salah satu lembaga pendidikan yang mentransfer nilai dan pengetahuan, memiliki social function dan sangat berperan dalam mewujudkan kehidupan yang penuh kedamaian dan harmonis bagi masyarakat pada umumnya. Pesantren di Indonesia berkembang dalam kerangka yang relatif khas dan memiliki watak yang berbeda dengan pendidikan sejenis di negara lain mengingat sifat damai yang dirasakan

\footnotetext{
${ }^{34}$ Yusuf al-Qardhawi, al-Shahwah al-Islamiyyah bayn al-Ikhtilaf al-Masyru' wa al-Tafarruq alMadzmum: Dirasah fi Fiqh al-Ikhtilaf fi Dhau' al-Nusus wa alMaqasid al-Islamiyah yang dikutip oleh Irwan Masduqi, Op.cit., hlm. 8.
} 
saat Islam masuk ke Nusantara. Hal ini berimplikasi pada watak keislaman yang damai di sebagian besar pesantren yang ada termasuk kontribusi yang diberikan bagi bangsa dan Negara. Pesantren tidak hanya menjadi lembaga yang identik dengan makna keislaman, tetapi juga mengandung makna keaslian Indonesia (indigenous). Pesantren senantiasa mentransmisikan pemahaman keagamaan Islam yang ramah, damai, toleran, saling menghargai, dan tidak radikal. Jauh dari doktrin radikalisme, saling mengkafir-bid'ahkan. Radikalisme agama sangat mengancam masa depan pesantren dan generasi bangsa. Pendidikan Islam (pesantren) yang mengajarkan kebencian terhadap pendapat dan keyakinan yang berbeda sangatlah tidak ideal bagi kelangsungan kebhinekaan dan keragaman di Indonesia. Hal ini juga tidak sesuai dengan misi perdamaian yang diusung oleh islam sebagai Din rahmatan lil'alamin. Pendidikan Islam yang inklusif, toleran, multikulturalis, dan humanis yang mengajarkan kasih sayang, kesantunan, menghormati orang lain, dan kerukunan, sehingga di masa mendatang dapat mendorong terwujudnya keharmonian dalam keberagamaaan di bumi Nusantara. Peran yang penting adalah untuk memberikan pemahaman kepada peserta didik mengenai pentingnya menentukan pilihan nilai yang akan dijadikan pegangan hidupnya, seperti kebebasan, persamaan, toleransi, kesetiakawanan, keadilan, kejujuran, dan kesabaran, baik dalam lingkup lembaga pendidikan, masyarakat, maupun negara.

\section{DAFTAR PUSTAKA}

A, Asrori. 2015. "Radikalisme di Indonesia: Antara Historisitas dan Antropisitas", Kalam, Vol. 9, No. 2, 2015, diakses di journal.radenintan.ac.id/index.php/KALAM/article/.../331/187, https://doi.org/10.24042/ klm.v9i2.331.

Al-Ghazali, A. H. 2002. Ihya'Ulumal-Din. Beirut: Dara-Kutubal'Ilmiyyah.

Al-Qardhawi, Y. 406 H. Al-Shahwah al-Isla-miyyah baynal-Ikhtilaf alMasyru'wa al-Tafarruq al-Madzmum:Dirasah fi Fiqh al-Ikhtilaf $f i$ Dhau' al-Nususwaal-Maqasid al-Islamiyah. Bankal: Taqwa.

Baharuddin. 2007. Pendidikan Alternatif Qaryah Thayyibah. Yogyakarta: LkiS. 
Baso, A. 2015. Islam Nusantara: Ijtihad Jenius dan Ijma'Ulama Indonesia. Jakarta: Pustaka Afid.

El-Fadhl, K. A. 2004. Atas Nama Tuhan. Jakarta: Serambi.

Esack, F. 2001. Al Quran, Pluralism, and Liberalism. USA: Pinguin Books.

Gay, G. "ASynthesis of Scholar shipin Multicultural Education in Urban Education Monograph Series". Washington: NCREL's Urban Education Program.

Hanafi, H. 2000. Islam in the Modern World: Tradition, Revolution and Culture. Cairo: Dar Kebaa Bookshop.

Jamaluddin, Eko Wahyu, Suprayogi, dan Aris Munandar. 2015. "Pembinaan Nilai Toleransi Beragama di Pondok Pesantren Annuriyyah Soko Tunggal Semarang", Unnes Civic Education Journal, Vol.1, No.1, diakses di https://journal.unnes.ac.id/ sju/index.php/ucej/issue/view/31 pada tanggal 02 Juli 2017.

Karwadi. 2014. "Deradikalisasi Pemahaman Ajaran Islam", Al-Tahrir: Jurnal Pemikiran Islam, Vol. 14, No. 1, diakses di http://jurnal.stainponorogo.ac.id/index.php/tahrir/article/view/71, pada tanggal 03 Juli 2018.

Kasdi, Abdurrahman. 2012. "Pendidikan Multikultural di Pesantren: Membangun Kesadaran Keberagamaan yang Inklusif", ADDIN, Vol.4, No.2, diakses di http://id.portalgaruda.org/ ?ref=browse $\&$ mod=viewarticle $\&$ article $=251937$ pada tanggal 03 Juli 2018.

Masduqi, I. 2013. "Deradikalisasi Pendidikan Islam Berbasis Khazanah Pesantren", Jurnal Pendidikan Islam, Vol. II, No. 1, diakses di http://ejournal.uin-suka.ac.id/tarbiyah/JPI/article/view/1125 pada tanggal 25 Mei 2018.

Mukhibat. 2014. "Deradikalisasi dan Integrasi Nilai-Nilai Pluralitas dalam Kurikulum Pesantren Salafi Haraki di Indonesia", Al-Tahrir: Jurnal Pemikiran Islam, Vol. 14, No. 1, diakses di http://jurnal.stainponorogo.ac.id/index.php/tahrir/ article/view/121, pada tanggal 03 Juli 2018.

Naim, Ngainun dan Achmad Sauqi. 2008. Pendidikan Multikultural: Konsep dan Aplikasi. Yogyakarta: Ar-Ruzz Media.

Prasodjo, S., et.all. 1982. Profil Pesantren Laporan Hasil Penelitian Pesantren Al- Falak dan Delapan Pesantren Lain di Bogor. Jakarta: LP3ES. 
Qodir, Z. 2013. "Deradikalisasi Islam dalam Perspektif Pendidikan Agama". Jurnal Pendidikan Islam, Vol. II, No. 1, 2013, diakses di http://ejournal.uin-suka.ac.id/tarbiyah/JPI/article/view/1129/1025 pada tanggal 2 Juni 2018.

Qodir, Z. 2003. Ada Apa dengan Pesantren Ngruki. Yogyakarta: Pondok Edukasi.

Ramadhan, Muammar. 2015. "Deradikalisasi Agama melalui Pendidikan Multikultural dan Inklusivisme (Studi Pada Pesantren al-Hikmah Benda Sirampog Brebes)", Jurnal SMART (Studi Masyarakat, Religi, dan Tradisi), Vol. 1, No. 2, diakses di https://blasemarang.kemenag.go.id/journal/index.php/smart/article/v iew/250, pada tanggal 01 Juli 2018.

Stompka, P. 2009. Sosiologi Perubahan Sosial. Jakarta: Kencana Prenada Media Group.

Wahid, A. 1999. Pondok Pesantren Masa Depan : Wacana Pemberdayaan dan Transformasi Pesantren. Bandung: Pustaka Hidayah. 